\title{
Henrietta L. Moore
}

Marilyn Strathern once famously claimed that there was no such thing as society (Strathern, 1988). It seems most likely that for the same reasons there can be no such thing as social theory, anthropological theory or queer theory. Bodies of knowledge are imaginatively recast as sets of differentiating relations. This renders the impetus of queer thinking problematic, for reasons that will be come clear as we proceed, for its impulses arise from an abiding wish to differentiate and to dissent. For this to be effective, earlier versions or accounts - whether theoretical, experiential or identitarian - have to be rendered oppositionally as totalistic, holistic and normative.

This text is proffered in the spirit of the volume, as a form of merographic, or partial engagement with the collective effort of the text. Its own impetus is one of reflection through analogy and metaphor. Analogies establish relations through comparison, and metaphors are particular ways of achieving or communicating connections. The slippage between the two in social theory is most often productive, but it has particular consequences when we move between domains of quite different orders.

Analogy and metaphor - and their internal workings - are Strathernian devices, since what her own thinking shares with the Melanesian context in which it developed is an insistence on the fact that both are acts, operations on the world. These devices are particularly important for anthropological analysis because together they work through revelation and displacement. This has the effect of bringing new relations, comparisons, insights, questions, concerns, maneouvres into view.

\section{Where is everywhere?}

Queer is about non-adherence to the norm, a powerful critique of normative and exclusionary practices, a move against the closure of political and social horizons. Queer theory has sought - as many chapters in the volume show - to expand its domain, working outwards from issues of sexuality and identity politics towards broader social horizons, insisting on the generative, the disruptive, the askance. Tom Boellstorff has suggested that rather than a theory, queer might be a method, less a noun and more of a verb, a set of situated practices for studying many things that are not self-evidently queer in the sense of relating to sexuality and adjacent matters (Boellstorff, 2010: 215): a view endorsed by many scholars who see queer as simultaneously a modality of being and of enquiry. An interesting tension emerges here between the propulsive direction of this broader understanding of queer practice and others - including students, activists and committed proponents - who voice two kinds of concerns. The first is a reluctance to move away from queer as an identity. The second is an anxiety that queer's commitment to antinormativity undermines those who wish to move towards defined identities associated with masculinity and femininity. Queer's commitment to transgression shifts uneasily alongside new forms of sexual politics associated with trans making and same sex marriage, for example, which seek recognition of social and sexual statuses and identities. At play here, as with all theorisations and forms of knowledge production, are questions of desire and investment, and how they play out (Weiss, 2016).

Questions of gender, sexuality and desire permeate social relations, and stand in metaphorically for many other forms of objects and relations in which we make 
investments. In many African contexts, ordinary objects of household provisioning connect to such matters via fertility and eating, as they do in many other societies. Freud suggested that we have to relinquish libidinal investments of many kinds in order to be able to redirect our energies into social life. Malinowski made a similar point arguing that cultural values must emerge from specific mechanisms for managing physiological drives (Malinowski, 1939). The ethnographic record is replete with examples, all extensively documented by anthropologists. This material emphasizes the material, somatic and sensate character of metaphor - its engagement both with the concrete world of materialities and the imaginary. The result is not a single coherent model, a totality, a map of society, but a set of incomplete, over determined and intersecting traces that are the product of specific and situated engagements with the material and the imaginary (Moore, 2007: 86-87). Partial connections are indeed how gender, sexuality and desire work.

As Strathern argues: 'A world obsessed with ones and the multiplications and divisions of ones creates problems for the conceptualization of relationships' (Strathern, 2004: 53). Here we arrive at some of the difficulties of genealogies. One of Marilyn Strathern's distinctive contributions is how we might set out to explore forms of knowledge construction through kinship. In this she follows, but does not reprise, Freud, Foucault, Lacan, Levi-Strauss, Rubin, Butler and others. The close relationship between kinship and various forms of social theorizing comes as no surprise since both are about our relations with others and how we connect to a world in which we are invested. Origin myths - indeed all versions of the question 'where do we come from?' - are an abiding concern of societies around the world, and also beloved of academic communities. One of the key tasks for an academic is to work out the kinship of ideas, their origins and potentialities. Most knowledge production works through forms of belonging and denial, by claiming descent or affiliation, or killing off ancestors. We invest heavily in our theoretical positions, and forms of theoretical belonging are always ways of setting out. Desire is an important part of academic life and what it does is to set things in motion by creating attachments and detachments, forms of relation that are also points of departure.

No wonder then that 'sexuality is everywhere: the way a bureaucrat fondles his records, a judge administers justice, a business man causes money to circulate; the way the bourgeoisie fucks the proletariat; and so on' (Deleuze and Guattari, 2004 [1977]: 322). Marilyn Strathern from her own starting point makes a similar kind of claim: 'Certainty itself appears partial, information intermittent. An answer is another question, a connection a gap, a similarity a difference, and vice versa' (Strathern, 2004: xxiv).

Plurality, uncertainty, cellular replications, fractals, non-linearity, potentialities - all are seductive in a post-plural world, a world of irreducible diversity and emergent forms, a world where authorities and authorship give way to potentiality and affect. This form of theorizing and its attendant practices are deeply seductive because they preface a world without limits, one where encounter prevails, where connection promises the possibility of a theory of everything, a oneness with the world. This finds its most prescient forms in queer ecologies and their related constellations of practices, where sex and nature form a common ground for theorizing about the multiple trajectories of power and matter. Cellular replication, materialisation and nonhuman forms of sexual and gender diversity provide the basis for non-teleological forms of relationality, sociality and pleasure (e.g. Mortimer-Sandilands and Erickson, 2010; Seymour, 2013). This powerful work reformulates the long-standing connections between sexuality and nature to develop a vision of interconnectedness that is powerfully seductive, even a 
form of romance with the world. Here the important move of dethroning anthropos flirts with the idea of a return to plenitude. Theories are always forms of belonging.

The pleasures of theorizing are an important part of theory development and formation. The vision of a world without boundaries which is also one of emergent properties is hard to resist. Perhaps there should be no concern about, or purpose to, resistance, but explication is a much harder task than simply deciding to relinquish epistemic control over human and non-human possibilities or pluripotentialities. If everything in the world is linked, if sexuality and gender are everywhere, if relations merely reveal further relation, then what kind of explanations are being offered of the world we inhabit, and how might those explanations connect to efforts to make that world more liveable for all?

In some very general sense, everything is connected, but theorizing is a form of selective amnesia. It has to be because it is impossible to take everything into account at once. This is one of the reasons for the formation of disciplines, the disciplining of directed intention and critical thought. Theoretical belonging has a purpose, but a good part of that purpose is given by context, by situatedness in time and space. This form of embeddness cannot be reduced to notions of potentialities or even emergent properties or forms of relationality, if by relationality we simply mean the potential for relations to be formed and revealed in various time dimensions. Concepts and modes of being are honed in different problems spaces and in different historical moments. The development of new concepts, new theoretical languages and forms of rhetoric allow new questions to be asked and new data to emerge. Consequently, theories are not just about thinking about the world, but also acting on it - like metaphors themselves. Here, human social life differs from that of materiality because in addition to the forms of becoming and relationality that the human and the non-human have in common, human social life is subject to the effects of ideational forms. Different theoretical traditions differ as to the valence, import and velocity of their impact, but in terms of the theories humans develop of the world, there is no doubt that these models are powerful. Two of the most powerful from the middle of the 20th century onwards have been gender and sexuality.

One purpose of theoretical critique is to rearticulate norms, and to shift positions, to create new forms of relationality and positionality. This both Marilyn Strathern and queer theorists have done with elan. Theoretical critique of this kind relies on processes of judgement, training, formulation, elucidation, attention and scrutiny. If there are problems with norms, the means and mechanisms, material and imaginary, through which we lead our lives then we have to imagine, develop and promulgate new ones. This involves both ethics and politics. Situatedness or contextualisation is of many kinds for all social theorists, and should not be imagined in the singular or as necessarily a matter of culture, geopolitical location or nationality, although all may be crucial. More relevant for anthropology is the evident nature of co-creation, the fact that fieldwork is a long process of learning. Situatedness is what drives anthropology and provides it with much of its power. It is an inductive discipline and particularity is what makes comparison powerful.

Clearly such a statement is overshadowed by the long history of colonialism and exclusionary theoretical formulations which have been critiqued in the social sciences, and in which queer theory plays its part. Comparative categories derived from western theorizing clearly risk drowning out and distorting the particularities of lives lived. However, most working anthropologists - and especially those who have an interest in theory - recognize that their theoretical preoccupations do not derive solely from disciplinary training and debate, but from contexts and forms of engagement in the 
world where they find purchase, engagement and power. Intellectual models depend for their impetus on imaginative possibilities they themselves cannot provide (Moore, 1994: chap 7). Anthropology is no longer a single discipline, if it ever was, but rather a multiplicity of practices engaged in a wide variety of social contexts. The move to make anthropological or social knowledge partial and plural is obviously insufficient (Moore, 1996: 2-6). But, the decentring of anthropos, the move to relationality, uncertainty, non-linearity etc. does little to recognize the production of other forms of knowledge with stated comparative, generalisable and universal claims (Moore, 2012a). The ethics of such a requirement is not materially advanced either simply by asserting the existence of multiple ontologies and multiple worlds, without also recognizing the comparative scope of other forms of knowledge, and their validity as social theory (Moore, 2015).

Ethics is a matter of theory as well as of method, and demands sustained reflection on what practices are adequate to the form of enquiry (Bell, 2007). But, social theory is not just about sustained reflection, as other social theorists outside the canon of western social theory have shown us, because it needs to be crafted from committed engagement with a purpose and/or a vision of the world. It's not just a matter of data and models. Here queer theory finds potential purchase. But, it is also worth recalling that the situatedness of knowledge is both its strength and a condition of its partiality. There are only ever partial connections between the figure of anthropos and the specific theories available during a particular historical period. Foucault tried to draw attention to this fact by emphasizing that there might come a time when the regime of sexuality would come to an end (Foucault, 1976: 152-59). His warning was intended to remind us that in future contexts and histories it might be necessary to resituate the sexual subject in regimes of power and affect that could not be captured appropriately by the languages and ruses of sexuality as concept, experience or fantasy. A time might come when sexuality would not over determine all other life projects and subject positions (Moore, 2012b: 15). In such a time, sexuality would no longer be a problematisation in Foucauldian terms. One question we might wish to ask is whether queer might be one of the names for such a moment. Is queer beyond sexuality? If so, what might postqueer signify? In what way could queer be beyond queer, and what kinds of things subjects, objects, relations - could be realised in such a world?

One difficulty here is that genealogies are a tricky business. They almost never work through complete processes of either replication or disconnection. Their preferred modus operandi seem to be folded forms of amplifying recursive relationality - very Strathernian in fact - where points of departure lead backwards and forwards simultaneously. In the social sciences, we most often figure these forms of recursive relationality as sets of multiple and multiplying differences. This is what is intended in most instances by the deployment of new terms such as post-plural, pluripotentialities, post-queer. They represent an attempt, a desire to signal something beyond the limits of language, category, position. It is also precisely why the authors in this volume link Strathernian recursivity to a radically queering potential. However, as the old adage goes 'every good metaphor contains its opposite', and terms such as post-plural and post-queer insistently refer back to their origins and the conditions of their own emergence as forms of knowledge production. But, their expansiveness, their radical relationality cannot capture the totality of process, any more than the notion of society captures all the relations which make it up. The story of everywhere will never capture the simultaneous versions of the relations between anthropos and world in their unfoldings, even when we deploy the analogies of nature, of cellular replication, of 
becomings, of life itself to assist us. As all scientists recognize, the closer you get to life the more it eludes you. There is always more to reality than meets the eye.

\section{This is a fridge magnet}

Analogies, as Marilyn Strathern argues, are constructions or reference points that create a revelation, they make things appear in the imagination (Strathern, 2011a: 252). The very act of redescribing one thing in terms of another creates a 'not-quite-replication' which both resembles and differs (Strathern, 2011b: 98). The result is a form of folded over estrangement. Metaphors often serve the same purpose and one of my favourites is: 'The attorney general is a jellyfish'. We know something new about one thing by juxtaposing it with another, creating similarity and difference simultaneously. As Marilyn Strathern asserts, this is not necessarily a matter of comparing things that are obviously the same, rather it is the very assertion of relationality that is productive (Strathern, 2011b: 96, 102).

In moving from category to plurirelationality/pluripotentialities, queer views itself as transgressive both in relation to its own genealogy of emergence in the social sciences, but also as a consequence of its hyper-relationality, the lack of boundaries between the human, non-human and material worlds, the act of queering those relationalities. There are a number of issues here, but one is a query about how - and for whom - the relations/encounters/intersections referred to should be understood as queer. Queer is a point of departure, displacement and unfolding with a particular history, but if plurirelationalities, encounters, ramifications, emergences are inherent in the world, then for most of that world they must by definition not be queer, at least in the terms in which queer theory and practice has defined the term. Queer cannot provide new forms of representational literalism. One might go further and suggest that a post-plural, pluripotential world is one in which the act of queering is logically unnecessary, since no boundaries or totalities are constitutive. In a world without limits, no metaphor of becoming, of pluripotentiality or of the post-queer, however well developed, could hope to provide an account of that world.

Marilyn Strathern's interest in the post-plural (2004: xvi) reprises a world where parts and wholes have no purchase, and where the severance of one form of relationship founds a further relationship (2011a: 261). This is an example of what she refers to as 'borrowing the insights without borrowing the substance' because it is an idea that follows productively from the Melanesian insight that through reproduction persons are both duplicated and divided, replicated and created anew as a set of productive differences (Strathern, 2011a: 262). Yet, Marilyn Strathern is also clear that while genealogies differentiate and replicate, they do not necessarily lead in one direction or operate on a single time scale. As she notes, postmodernism does not come after modernism, it was found within it, it was already there (Strathern, 2011a: 253). Part of the work of the analyst is to reveal or make evident relations that already exist. But, the queering of categories, relations, pluripotentialities began long before queer became one of the names for these processes.

The notion of transgression provides the opportunity for a moment of reflection here. Transgression is an act that depends on the idea that we are both telling it like it is, and telling it like it is not. It thus depends on a certain adherence to forms of representation. A good example might be Magritte's image Ceci n'est pas une pipe. This is a familiar work and its premise is that for an image to find its significance, it must be displaced from its natural given state, from the taken for granted. It is not just that the image in the art work is not a pipe, but that it seeks to destabilize the relationship between 
representation and reality, to undercut the literalism of the sign's relation to the world. From a genealogical point of view, it is probably worth recalling that it was painted a decade or so after the publication of Saussure's work on the arbitrary relation of the sign.

The desire to unsettle the taken for granted, to be transgressive, is a modernist aspiration, and as such marks out the traces of a modernist project within queer theory. However, modernism, as Foucault argued, is not an epoch, but a relation. Modernism, like many transgressive and leftist movements, harbours a desire to tell it like it is, to partake of representational realism. Marilyn Strathern also retains a commitment to literalism, to uncovering a truth: 'Making the implicit explicit I refer to as an act of literalisation, that is, a mode of laying out the coordinates or conventional point of reference of what is otherwise taken for granted' (Strathern 1992: 5). However, as the implicit is made explicit, at the very moment the arbitrary relation of the sign is made evident, a nostalgia for an authentic connection between sign and world is realized. Modernism consistently revealed the image's power of allusion and yet mourned for an authentic connection between sensation/nature/world and the sign (Clark, 1999: 9-10). The metaphor for this folded over, recursive relation of displacement and connection is in the materialism of the art work itself. Yet, modernism, like modernity, had no power to cohere as a totality. It is recognisably itself, and yet also other to its multiple selves. Theories, like art works, are very often other to themselves. Magritte's image is now so popular that its capacity for shock has been transmuted into a consumable pleasure. For all those who may have seen the work itself, it is familiar to many more in its most popular instantiation as a fridge magnet. The queer potential of fridge magnets has yet to be realized.

However, the process of queering, rather than queer theory per se, suggests other parallels with the making of images that are instructive. In 1928, Magritte painted a work entitled L'Homme au Journal. It consist of four panels, the first of which depicts a man seated at a table reading a newspaper with his back to a window. The adjacent three panels show the same room but with the man removed. In each case, there are very slight displacements of the image, slight changes of perspective. The only way to spot them is by looking at the shadows the objects cast. Once the image of the man is removed, other signs cannot stay constant, the meaning of the scene is uncertain. It is no longer a man reading a newspaper. These plural perspectives become perspectives for one another, they show the world making meaning in the absence of the meaning maker. They are an attempt both at denaturalization and at recuperation of the object world, materiality as is. The images are in juxtaposition, both partial and merographic, but no one view offers a totalizing vision.

The idea that there is more to the world than any one perspective can offer, and that this is revealed through a world of objects has a long history. But, Magritte's image works precisely because it does not specify its intentions, it is open, it is not providing a narrative, drawing a conclusion, marking out a pathway forward. It is an indicative proposition, an encounter at best. Its purpose is contrariness, estrangement, arbitrariness. The queering of all relations - both human and non-human - has a similar purpose, it does not lay out a pathway other than one of transgression and displacement. The political at the core of queer is the romance of the antinormative, the idea of a world of endless possibilities within relationality. This notion of queering works through the potentialities of obfuscation and association rather than through the effects of positionality or narrative. It is at odds with the identitarian elements of its own emergence and with the fact that it is permanently marked by sexuality. Clearly, it is 
impossible to reform queer's marking by sexuality since this is constitutive of the heart of the discourse. Queer does not come after sexuality but is found within it.

\section{What is social change?}

The challenge with academic genealogies is that they are not cartographies of descent, rather like formal kinship charts they are not accurate reflections of the lived world they seek to capture. Marilyn Strathern's notion of the post-plural is a space of nonbelonging, but yet retains an oblique connection to the temporal and spatial contexts of its production. Foucault used the notion of problematization to signal the crucial but oblique relation between historical circumstance and the theories of anthropos and the world thus occasioned. One of the abiding mistakes of social sciences is occasionally to mistake changes in theory for changes in the world or to imagine that the one can substitute for the other. Part of the problem here is the focus on difference and differentiation. The source of these ideas in social science theorising are various, but since at least the end of the nineteenth century, biology has played a crucial if often under theorised role. Biology, and particularly cellular replication, underpins the work of Deleuze (1991), Massumi (2002), Connolly (2011) and a host of contemporary writers. It is therefore fundamental to queer theorizing (Kirksey, 2018; Lowe, 2010) in ways that are often oblique rather than explicative. However, the social worlds of humans do not self-organise in the way that cellular replication and the materialities of the (so-called) natural world do. The very analogy of social life as a series of becomings or emergences is predicated on the non-linear potentialities of living forms, but it finds purchase within queer practice because it plays out the romance of the human at one with the natural.

While forms of becoming are certainly not captured by the notion of human time as history, we should be wary of subsuming the latter within the differentiations of becoming. Redundancy, reversals, needless repetitions and nostalgia are all part of human history and play a huge part in driving social change and creating dysfunctional forms of political economy. The notion of becoming in the social sciences risks reducing the plural temporalities of human (and non-human) time to the monotemporality of becoming (Born, 2010: 243). Becoming as an emergence is not actually moving anywhere, as a series of emerging relationalities it is not marked by the human or the sign. The further risk is that relationality understood as endlessly ramifying difference everywhere - a queer universe - fails to distinguish between different kinds of relationality, with different temporal and value dimensions. If postplural relationality or pluripotentialities (Connolly, 2011: 116) become the new queer universe of the non-normative then we might need to watch out for what the normative is up to.

The very assumption that somehow a shift from performance to positionality and onwards via multiplicity and the post-plural to processes of becoming charts a form of progress in social science theorizing should, at the very least, be interrogated (Grosz, 1999). Rather like the view that we have somehow been moving along a progressive continuum from gender via sexuality to queer and post-queer. Of course, in social theory, as in life, ordinary everyday experiences of change, continuity, rupture and epoch sit alongside and are simultaneous with the objectification, categorisation and manipulation of history by those in power (Hodges, 2008: 416). However, there is a risk that all these questions of history and social transformation fade into emergent potentialities or get refigured as simply the intricacies of personal struggle and identitarian politics. If queer becomes redefined as 'resistance to a wide field of 
normalisation' (Weiss, 2016: 631), will it be sufficient to expose forms of political economy and power simply by queering them, especially when queer practices are allied to a philosophical commitment to a world of becoming, of emergent possibilities? If we take as instructive the changes in sexual identities and sexual regulation over the last 30 years around the world. It is evident that enormous changes in identities, legalities and practices have taken place. However, it is equally evident that all such change is embroiled in relational forms of anachronism and repetition that are not well captured by differentiation and the non-identitarian precisely because they are folded over versions of earlier positions, experiences, understandings and trajectories. Consequently, when we reflect on the issues of same sex marriage and the rise of the trans movement, for example, we see and experience their liberatory potentialities, but we recognize also their reemergent identitarian and classificatory propensities. Sexualities, identities, objects of desire, audiences, activists and others are inhabiting multiple and not necessarily co-incident temporalities, they are literally out of time with each other. The realization of possibilities in human social life requires effort, they do not just become or emerge. This is one of the definitions of the political.

What then does history mean for human life in its pluripotential relations with materialities, the non-human and the more than human? Paul Rabinow has been exploring a version of this question for years in his reflections on the contemporary. He is clear that the contemporary is not an historical epoch (Rabinow, 2007: 2), but an emergent relationship. His use of the term emergent is redolent of other terms including adjacent and accompaniment (Rabinow, 2011). His interest is indeed in relations, in what is inherent in interactions themselves and how trajectories emerge out of those interactions. In a sense, everything is contemporary. He recognises the difficulty of this position by asking: 'How is one to decide where one is? And where is one going?' (Rabinow, 2007: 12). Issues of discernment and judgement are important, the act of making things adjacent or contemporary is an act, and fundamentally a matter of politics. It is not sufficient to roll up all these difficulties into notions of becoming and emergence. The vocabularies of analysis work through analogy and metaphor, and as such they are acts upon the world. The desire to capture the world in its fullness is an old one and it is refigured anew in the literalism of theory as sets of emergent, pluripotential relations. The social sciences have a duty not just to describe the world as it is or to be at one with its potentialities, but to attend to the distortions and demands that humans make on that world, and to orient their critique towards a life that is more liveable for all of us.

\section{Bibliography}

Bell, V 2007 Culture and Performance: The Challenge of Ethics, Politics and Feminist Theory. Oxford: Berg

Boellstorff, T 2010 'Queer techne: two theses on methodology and queer studies' In (eds) K Browne and C Nash Queer Methods and Methodologies. Farnham: Ashgate

Born, G 2010 On Tardean Relations: Temporality and Ethnography," in The Social After Gabriel Tarde: Debates and Assessments (ed) M Candea. London: Routledge

Clark, T.J. 1999 Farewell to an Idea: Episodes from a History of Modernism. Yale, NH: Yale University Press

Connolly, W 2011 A World of Becoming Durham, NC: Duke University Press 
Verso header

Deleuze, G 1991 [1966] Bergsonism. New York: Zone books

Deleuze, G and Guattari, F 2004 [1977]. Anti-Oedipus. London: Continuum

Foucault, M 1976 The History of Sexuality, Volume I: An Introduction. New York: Pantheon Books

Grosz, E 1999 Becomings: Explorations in Time, Memory and Futures. Ithaca, NY: Cornell University Press

Hodges, M 2008 'Rethinking Time's Arrow: Bergson, Deleuze and the Anthropology of Time' Anthropological Theory 8(4): 207.

Kirksey, E 2018 'Queer love, gender bending bacteria, and life after the anthropocene'. Theory, Culture and Society 0(0): 1-23

Lowe, C 2010 Viral clouds: Becoming H5N1 in Indonesia. Cultural Anthropology 25(4): 625-649.

Malinowski, B 1939 'The group and the individual in functional analysis' American Journal of Sociology 44(6):938-964

Massumi, B 2002 Parables for the Virtual: Movement, Affect, Sensation. Durham, NC: Duke University Press

Moore, H.L. 1994 A Passion for Difference. Cambridge: Polity Press

Moore H.L. 1996 'The changing nature of anthropological knowledge' In H.L. Moore (ed) The Future of Anthropological Knowledge. London: Routledge

Moore H.L. 2007 The Subject of Anthropology. Cambridge: Polity Press

Moore H. L. 2012a ‘Fantasies of cosmopolitanism' In R Braidotti, P Hanafin, B Blaagaard (eds) Cosmopolitanism: An Interdisciplinary Exploration. London: Routledge

Moore H.L. 2012b 'Sexuality encore' In P Aggleton, P Boyce, H.L. Moore and R Parker (eds) Understanding Global Sexualities: New Frontiers. London: Routledge

Moore H.L. 2015 'Living in molecular times' in B. Blaagaard and I van der Turin (eds) The Subject of Rosi Braidotti: Politics and Concepts. London: Bloomsbury

Mortimer-Sandilands, C and B Erickson (eds) 2010 Queer Ecologies: Sex, Nature, Politics, Desire. Bloomington: Indiana University Press

Rabinow, P 2007 Marking Time: On the Anthropology of the Contemporary' Princeton: Princeton University Press

Rabinow, P. 2011 The accompaniment: Assembling the Contemporary. Chicago: University of Chicago Press 
Seymour, N 2013 Strange Natures: Futurity, Empathy, and the Queer Ecological Imagination. Champaign: University of Illinois Press

Strathern, M 1988 The Gender of the Gift: Problems with Women and Problems with Society in Melanesia. Berkeley: University of California Press

Strathern, M 1992 After Nature: English Kinship in the late Twentieth Century. Cambridge: Cambridge University Press

Strathern, M 2004 Partial Connections. Oxford: AltaMira Press

Strathern, M 2011a 'What is a parent?' HAU: Journal of Ethnographic Theory $1(1): 245-278$

Strathern, M 2011b ‘Binary licence’ Common Knowledge 17(1): 87-103

Weiss, M 2016 'Always after: desiring queerness, desiring anthropology' Cultural Anthropology 31(4):627-638 